\title{
Demographic Potential of the Klyazma River Basin-History of Development and Present State
}

\author{
Trifonova Tatiana Anatolievna ${ }^{1} \&$ Repkin Roman Vladimirovich ${ }^{2}$ \\ ${ }^{1}$ Lomonosov Moscow State University, Moscow, Russia \\ ${ }^{2}$ Vladimir State University named after Alexander and Nikolay Stoletovs, Vladimir, Russia \\ Correspondence: Trifonova Tatiana Anatolievna, Lomonosov Moscow State University, GSP-1, Leninskie Gory, \\ Moscow, 119991, Russia. E-mail: tatrifon@mail.ru
}

Received: October 15, 2014

Accepted: October 25, $2014 \quad$ Online Published: December 7, 2014

doi:10.5539/mas.v9n2p78

URL: http://dx.doi.org/10.5539/mas.v9n2p78

\begin{abstract}
The aim of this research is to analyze the demographic situation of the river Klyazma basin in the post-Soviet period and throughout the history of development and settlement of the region; identification of the major centres of vectors differentiation of population development in the examined basin; analysis of socio-economic, natural and environmental factors affecting the population distribution within the basin and demographic processes that are typical for the region. We must take into account that the population demographics of the region is largely dependent on diversity and state of resources of the area and their involvement into the economic sphere, however, it is obvious that the state of the economy is also a key factor in ensuring the sustainability of ecosystems and geo-systems of the river basin. The river Klyazma basin area has a long historical path of development and transformation of natural systems into natural and man-made landscape complexes. There is a need for new intensive measures to enhance demographic potential of the territory and to stabilize the ecological and economic situation.
\end{abstract}

Keywords: river drainage basin, natural ecosystems, geo-systems, demographic potential, demographic crisis

\section{Introduction}

Drainage basins are integral geographic systems and are examined by us, not only in terms of physical, but also of socio-economic geography and geo-ecology. Historically, river systems were the ways of land development and development of the national identity. Population emerging within the basin, its national and cultural composition, demographic and economic potential determines the nature of wildlife in the region, given its natural conditions (Korytny, L. (1991); Korytny, L. (2001); Repkin, R., \& Tyulina, V. (2002); Trifonova, T., et al. (2012)). A developing economy transforms natural ecosystems and, as a consequence, functioning of the basin itself. Environmental problems often manifest themselves at the local level as centres of ecosystems pollution and degradation of watercourses, as well as centres of social and economic tension. Over the centuries, the key to the state and national security of Russia was the highest demographic potential of the population, primarily Russians. One of the main centres of Russian people's origin and the origin of the Russian national identity was the territory between the Volga and the Oka, the drainage basin of the river Klyazma occupies most of it (Makarov, N., et al., 2005; Vodarsky, Y., \& Kabuzan, V., 2011). To this date, regions of the long habitable and populated European Centre are undergoing a profound demographic disaster characterized by depleted reproductive potential. The Klyazma river basin is also characterized by a tendency of the demographic crisis - a profound violation of human reproduction: reduction of the birth rate, aging population, increasing number of elderly and people living alone. Formation of depopulation trend of birthrate is prolonged and many changes in the demographic minds of citizens, especially in the norms of reproductive behavior, have a long history, spanning over several generations. Demographic policies aimed at correcting this trend should be long-term, forward-looking, but in terms of geopolitics the Klyazma basin region should be among those with the highest priority in implementing population programs (Kochurov, B., 1992; Muravyova, M., 2011; Demographic Yearbook of Russia, statistical Yearbook, 2010; Benini, L., et al., 2010). Social services and economy of the region of the Volga-Oka interfluve and of all the country as well need radical reforms.

Currently principles of the state policy in the field of population are elaborated. Conceptual and programme documents, which determine objectives, priorities and measures of the demographic policy of the Russian 
Federation are prepared. In 2001, the Russian Government adopted the Concept of the demographic development of the country for the time period up to 2015, in which the most important directions of the state policy of the Russian Federation in terms of population were formulated. The main priority of the Russian demographic policy at the present stage is improvement in health status of the population, increase in life expectancy, decline in death rate, birth rate stabilization and strengthening of the family. The trend for demographic indicators improvement in the country as a whole and optionally is the result of implementing the programme activities, such as "Main directions of the family policy", "Children of Russia" and (Demographic Yearbook of Russia, statistical yearbook. (2010)). Within the specific system of the particular territorial drainage basin of the Klyazma river, the demographic situation remains acute, it significantly differentiates by municipal administrative regions and districts included in the basin.

\section{Objects and Methods}

We used a basin approach (Korytny, L. (2001); Trifonova, T., et al. (2012); Xiaoxu, J., et al. (2011)) and the object of the study was the river Klyazma catchment area located in the centre of the European part of Russia and corresponding to the Volga-Caspian basin (Dobrovolsky, G. (2005); Kolomyts, E. (2005); Mishchenko, N.V., et al. (2009)).

The total catchment area is about 42.5 thousand $\mathrm{km}^{2}$, which amounts to about $17.5 \%$ of the area of the Oka River basin and more than 3\% of the Volga basin. The Klyazma River, the largest left tributary of the Oka River, originates in Solnechnogorsky district of the Moscow region (source coordinates 56 $11^{\prime} 13^{\prime \prime} \mathrm{N}$ and $37^{\circ} 10^{\prime} 30^{\prime \prime} \mathrm{E}$ ). The mouth area location is in the Gorokhovetsky district on the border of Vladimir and Nizhny Novgorod regions $\left(56^{\circ} 10^{\prime} 05^{\prime \prime} \mathrm{N}\right.$ and $\left.42^{\circ} 58^{\prime} 09 " \mathrm{E}\right)$. The river is $686 \mathrm{~km}$ long. Water flow is about $237 \mathrm{~m}^{3} / \mathrm{sec}$. The Klyazma river basin has quite a developed river network. 222 rivers and streams join it. The largest tributaries are: from the left - Ucha, Vorya, Sherna, Kirzhach, Peksha, Koloksha, Nerl', Uvod', Teza and Luh; from the right - Polya, Sudogda and Suvorosch. According to water regime, Klyazma and its tributaries are typical lowland rivers: their slopes are small, slow flow, great bed tortuosity. The basin rivers are fed by precipitation (mostly snow), wetlands and groundwater (Figure 1).

The Klyazma river basin is located on the territory of the regions belonging to the Central Federal District: Vladimir, Ivanovo, Moscow and Yaroslavl regions, as well as the Volga Federal District - Nizhniy Novgorod region and flows to the administrative boundaries of the Russian capital - the city of Moscow on three areas: on the northern border of Zelenograd administrative district (Zelenograd), on the parts of Molzhaninovsky district of the Northern Administrative District and the Northern Region of the North-Eastern Administrative District. Most of the basin (about 19,000 $\mathrm{km}^{2}$ ) belongs to the Vladimir region.

To assess the demographic potential of the Klyazma basin we used: 1 . Electronic maps of the study area: the topographic map (1:200,000), a map of the administrative-territorial units, ecological zoning map and others; 2 . Statistical and published data describing the landscape structure, climate, soil and vegetation conditions, historical, archaeological, administrative-territorial and demographic characteristics of the study area; 3. GIS analysis is based on the program Arc GIS (Blakemore, M., 1988; Fries, C., 2000; Dengiz, O., \& Sağlam, M., 2012; Hanqin, T., 2010).

\section{Results}

Now over 3.3 million people live within the river catchment, with about a third of the population directly living along the Klyazma banks. Such cities, significant to the history and development of the country, are situated on the river as Dolgoprudniy (population - 95 thousand people in 2013), Korolev (187 thousand people), Schyolkovo (113 thousand people), Noginsk (102 thousand people), Orekhovo (121 thousand people), Vladimir (348 thousand people), Kovrov (142 thousand people), smaller cities and towns, and many rural settlements. The largest city fully situated within the basin territory - Ivanovo with the population - 409 thousand people (2013). The main part of the city has a population of 10 to 50 thousand. The vast majority of the population of the basin lives in cities or urban-type settlements - more than $80 \%$ (urban population of Russia - 73.86\% (2013)). 


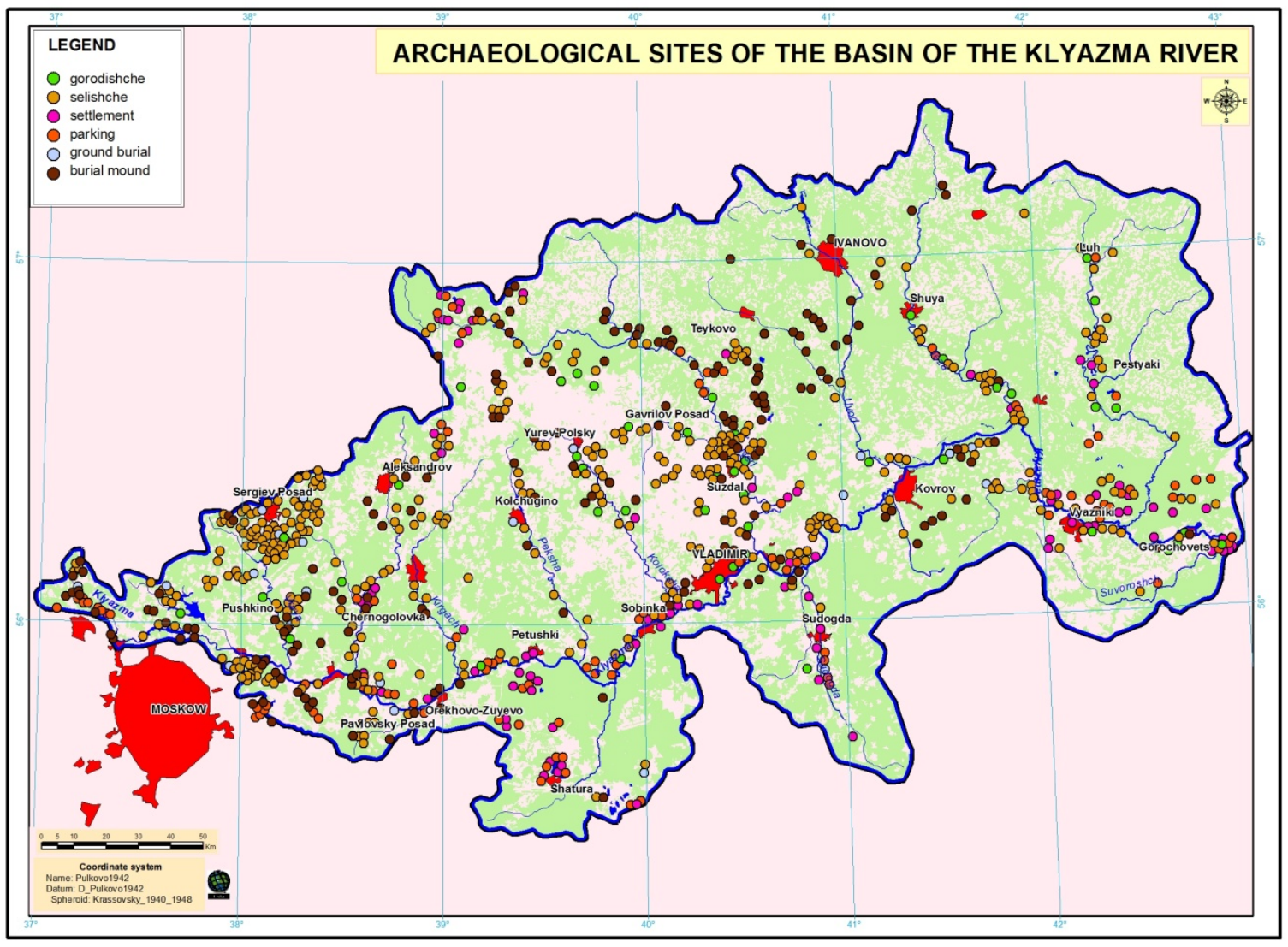

Figure 1. Archaeological monuments of the Klyazma basin

A little over a hundred years ago, the situation was reversed. For example, in 1897 the percentage of rural population of the region - peasants was more than $85 \%$ of the population, and by the middle of the twentieth century - less than $50 \%$. The transition from a rural to an urban way of life occurred in Russia in several historical stages throughout the twentieth century. For residents of the region under study this transition was very painful. The revolutions, the Civil and Great Patriotic War, the collectivization and industrialization, restructuring and collapse of the USSR undermined traditional systems of management and reproduction, population age and gender balance, contributed to population migration to the cities and outside the region, triggered restructuring of landscape features of the region.

The average population density of the basin is about 77.5 people per square kilometre, which is significantly higher than national average -8.39 people per sq.km. At the same time, the average density of the population in the Moscow region areas - 158.82 people per sq.km, but the Vladimir and Ivanovo regions - about 48 people per sq.km. The highest density takes place in the districts closest to Moscow: Dolgoprudniy - 3080, Korolev - 3573, Khimki - 1880, Balashikha - 1059 and districts: Mytischinsky - 489.9, Pushkin - 314.2 and Schelkovskoye 274.1 people per sq.km. In the peripheral areas the population density is much lower: Pestyakovsky -6.22 , Verhnelandehovsky -8.45 (areas of Luhskjye Polesye) and the Ilyinskiy district -6.71 people per sq.km.

Rural population of the basin continues to shrink. The number of rural settlements where there is not a single permanent resident is growing. In some districts rural population still dominates over urban (Verhnelandehovsky, Ilyinsky, Kameshkovsky, Komsomolskiy, Lezhnevskaya, Luhsky, Palekhskiy, Sudogodskiy, Suzdalskiy, etc.). The minimum density of the rural population is in the Pestyakovsky district of the Moscow region -2.85 people per sq.km, the maximum - in Ramensky - 79.33, Mytischinsky - 57.02 and Noginsky - 52.40; these numbers are provided mainly by the population not engaged in agriculture and permanent population of suburban settlements.

Most of the population of the basin is concentrated in the western territory of the capital region and is a part of the Russian largest Moscow metropolitan area with the population of about $16-17$ million people. 
Mytischinskaya-Pushkinskaya-Schelkovskaya agglomeration (948.9 thousand people) is the largest in terms of population in the Moscow region, almost fully integrated into the Klyazma river basin borders (Figure 2).

The results of the processed data on the population dynamics are presented in the form of cartographic material (see Figure 3), and peculiarities of the age and sex structure of the population of the Vladimir region are characterized by the diagram (see Figure 4).

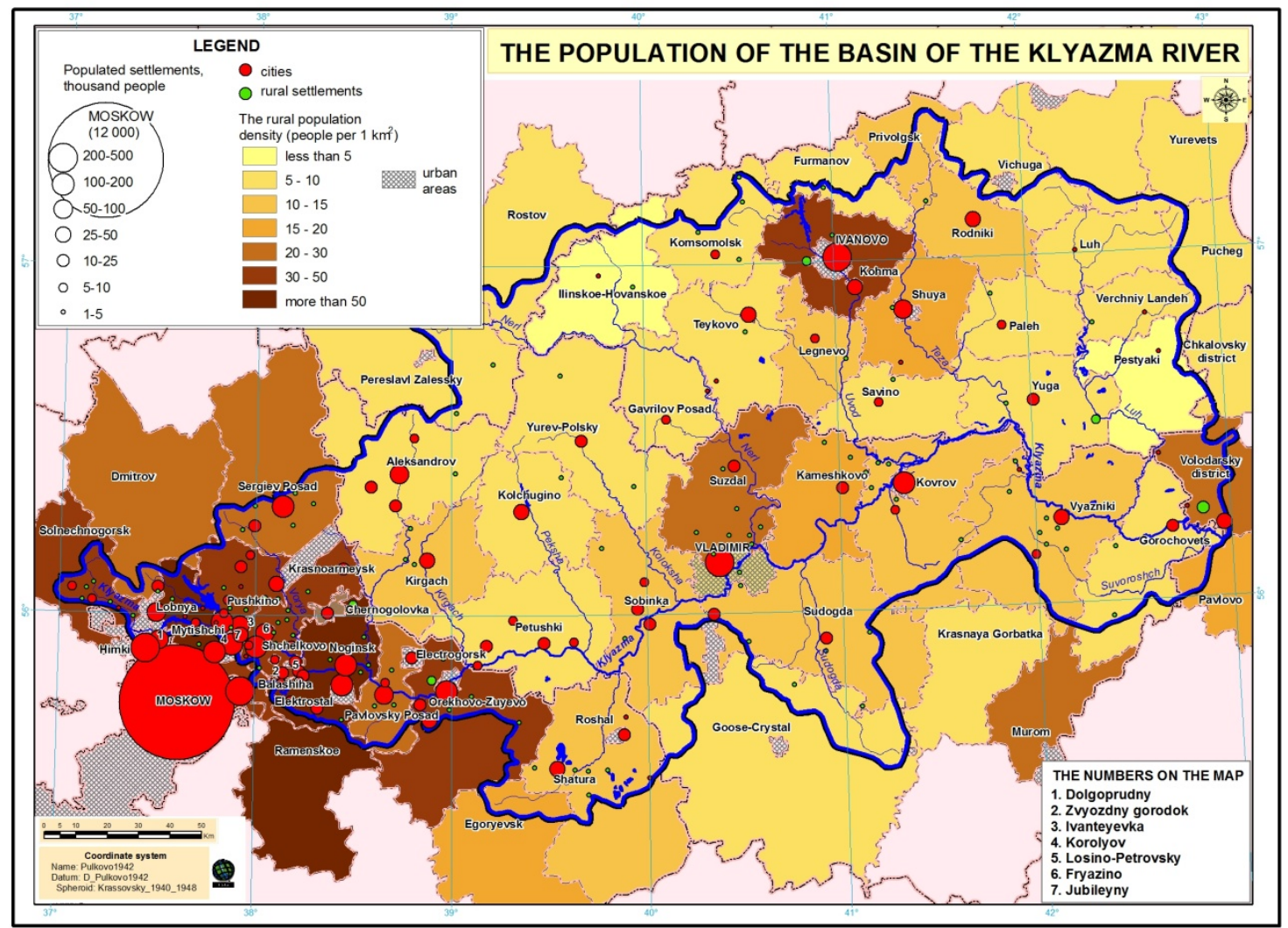

Figure 2. The population distribution of the Klyazma river basin

\section{Discussion}

Analysis of the research results showed that the history of the region development greatly influences modern landscape area appearance. The Klyazma river basin corresponds to early-developed regions of Russia. People have long dwelt on the riverbanks and the entire basin. Archaeologists discovered prehistoric people's sites of the Palaeolithic era (Sungir), Mesolithic and Neolithic eras, and settlements of Dyakovo Culture (Archaeological Map of Russia. Ed. Krasnov, Y. (1993-1995)). The sites were usually located close to water objects (remnants of river terraces, capes, etc.). In more recent times, the riverbanks were inhabited by Finno-Ugric tribes of Mescher, Mer and Murom, and then the Slavs. Monuments of the Finno-Ugric population - Meri are opulently represented on the basin area. The system of medieval Slavs settlement, starting from the second half of the $10^{\text {th }}$ century, is being reconstructed through preserved archaeological sites - ancient settlements: Tsarevo, Mogutovo, Osovets, Luchino, Mstislavl, Yuriev Polsky, Kideksha, Vladimir, Suzdal, Starodub, Yaropolch, Gorohovets and others (Golubeva, L. (1987), Makarov, N., et al. (2005); Makarov, N., et al. (2013)).

The development of all the northeast of Russia is associated with the river and its tributaries, starting with the Vladimir-Suzdal principality (the $7^{\text {th }}$ century), the centre of which became rich fertile soils of Opolye. At that time, the river and its tributaries were used for navigation all year round, which made it possible to extend its influence far and develop the economic foundation for the future economy of the territory (Figure 1). In the 20th century, a territorial-sectoral structure of the economy formed in landscapes highly modified for many centuries. Vicinities of Moscow in the western part of the region in the Klyazma head reach underwent the greatest human impact, the next satellite towns of Moscow, the part of the Moscow metropolitan area are situated there.

In Moscow and the Moscow region, a steady increase in population is observed. Population growth comes 
mainly at the account of increasing the number of residents in the capital and the surrounding towns. Overall population growth in the capital region is not achieved due to natural demographic indicators, but due to the positive balance of external migration and population entry from the periphery. Thus, the most rapidly growing cities, partly outside the Klyazma basin are Balashikha - 235 thousand people (245 thousand people in the municipal district) with an increase of about 100 thousand people for 20 years, and Khimki -221 thousand people, the increase - 90 thousand people (including the town of Shodnya (27 thousand people), which in 2004 became a part of the city as the micro district). A significant part of the economically active population of the Moscow suburbs is employed in Moscow and commutes. A significant amount of daily commuting workforce is characteristic black particularly from the nearest Moscow suburbs. A similar trend is characteristic for the country as well in recent years, so that migration growth in Russia in 2010 for the first time fully compensated the natural decline in population (Census, 2010).

Nevertheless, according to the annual report concerning Population Fund of the United Nations in 2011, in Russia on the background of the intense economic and environmental situation, the demographic crisis still holds - a profound infringement of human reproduction. Manifestation of the recent crisis refers to the beginning of the 1990s. The birth rate in Russia doesn't reach the level necessary for simple reproduction of the population. It was only in 2013 that the natural population decline in Russia for the last 20 years was replaced by population growth. This transition within the Klyazma basin district in 2013 failed to appear in any one of the subjects of the federation (an increase in the capital was achieved through the expansion of borders) (Population of the Russian Federation, 2013).

A natural decline in population is characteristic for the basin as a whole. The sharp decline in natural population growth, manifested from the 90s of the last century, was the result of the superposition of two negative trends: the dramatic birth rate decline and a significant increase in mortality during the economic crisis, as well as the outflow of working population due to lack of jobs. In recent years, the natural decline in population decreases, especially in the Moscow suburbs (from $8.5 \%$ in 2005 to $2.4 \%$ in 2012).

The current level of the birth rate in the region is significantly lower than the level necessary for simple reproduction - replacement of parents' generations with their children (the desired ratio is 2.15). The number of dead people exceeded the number of newly born by 1.3-1.5 times.

The analysis of overall population mortality indicators showed significant differences in administrative areas. The highest mortality rates are registered in Selivanovsky, Vyaznikovsky, Pestyakovsky and Puchezhsky regions (from 21.4 to 33.3 people per 1 thousand of population with an average of 17.6). At the same areas the lowest birth rates are noted (6.8-10.8 people per 1 thousand of population), which leads to high levels of natural population loss. The high mortality rate among men of working age is worth mentioning, as it is much higher than the mortality rate of women.

The indicators of natural population loss in the basin are significantly higher than the national average, especially in the remote hinterland, peripheral in relation to the metropolitan area, where an outflow of population is observed for a long time. For example, Vyaznikovsky district (without Vyazniki) lost $46 \%$ of the population over the past 50 years, Selivanovsky $-50 \%$, Furmanovsky $-60 \%$, Luhsky $-64 \%$, Ilyinsky $-65.5 \%$, respectively. The situation worsened during the crisis of late $80 \mathrm{~s}-$ mid $90 \mathrm{~s}$ of the twentieth century, and a particularly difficult situation in most parts of the basin and cities formed at the beginning of the 21st century (Table. 1, Figure 3 ).

A typical example is a typical town of the region - Vyazniki, the historic centre of light industry. The town's population had multiplied four times over one hundred years, while during the period from 1959 to 2010, the town's population had increased by only $4.5 \%$, and by 2014 it had fallen to the level of the mid-twentieth century.

Table 1. Demographic indicators of some municipalities in the Klyazma river basin. 2010

\begin{tabular}{|c|c|c|c|c|}
\hline Town / Distric & $\begin{array}{r}\text { Birth rate (people per } 1 \\
\text { thousand residents) }\end{array}$ & $\begin{array}{r}\text { Mortality rate } \\
\text { (people per } 1 \text { thousand } \\
\text { residents) }\end{array}$ & $\begin{array}{r}\text { Infant mortality } \\
\text { (mortality of } \\
\text { children } \\
\text { under the age of 1) } \\
\end{array}$ & $\begin{array}{r}\text { Natural increase } / \\
\text { decrease } \\
\text { (people per } 1 \\
\text { thousand residents) }\end{array}$ \\
\hline Vladimi & 10.9 & 14.7 & 6.4 & -3.8 \\
\hline Ivanovı & 10.6 & 15.9 & 8.0 & -5.3 \\
\hline Raduzhn: & 11.3 & 8.7 & - & 2.6 \\
\hline Vyaznikovsk! & 10.8 & 21.4 & 6.8 & -10.6 \\
\hline
\end{tabular}




\begin{tabular}{|c|c|c|c|c|}
\hline (district & & & & \\
\hline $\begin{array}{r}\text { Puchezhsk: } \\
\text { (district }\end{array}$ & 8.7 & 33.3 & - & -24.6 \\
\hline $\begin{array}{r}\text { Selivanovsk! } \\
\text { (district }\end{array}$ & 10.4 & 25.5 & 10.1 & -15.1 \\
\hline
\end{tabular}

Steady population growth was observed only in the regional centres and towns of the "close" Moscow suburbs. In Vladimir the population growth was 224\%, from 1959 to the present time, reaching 347,930 people (2013). The increase peak 356,000 occurred in 1992, in recent years there has been population decline which was compensated by expanding the city borders. In Ivanovo the population grew from 335,000 (1959) to 480,400 (1992), and then decreased by 71 thousand people up to 409,075 inhabitants (2013).

The special situation is in the satellite towns of Moscow with the developed innovative economy and the knowledge-based structure of industrial production. In the twentieth century, they have become compelling centres of growth. Some of them have grown more than $4-5$ times bigger over fifty years: Lobnya has grown by $506 \%$, and Khimki and Korolev (Kaliningrad) - 340\% each, Balashikha $-275 \%$, Pushkin $-245 \%$, etc. Such a significant increase is provided by influx of foreign migrant workers who have settled for permanent residence, but not due to natural population movement indicators, which remained below the national average.

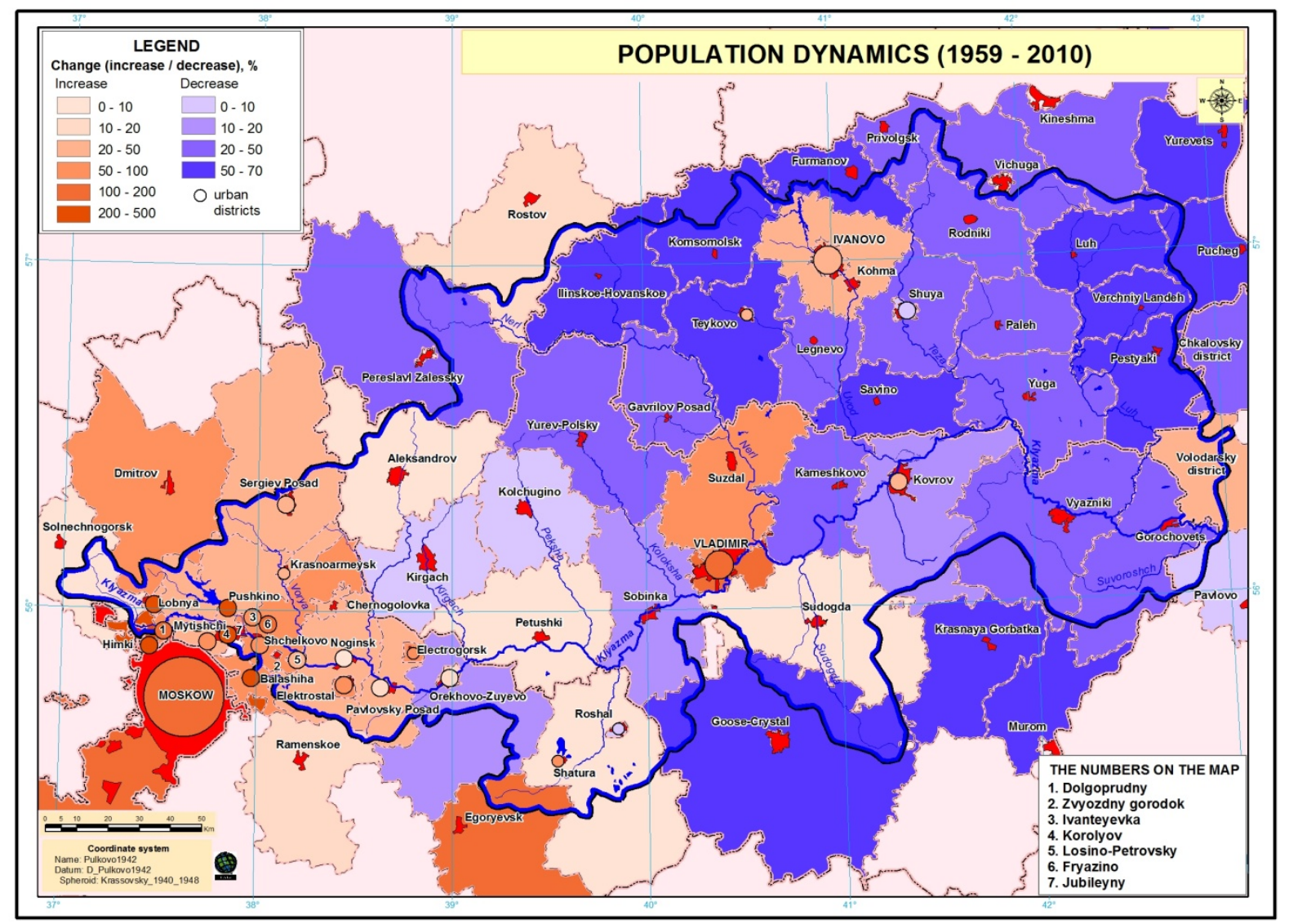

Figure 3. Population Dynamics of the Klyazma basin during 1959-2010

According to the 2010 census, the number of female population is significantly higher than the one of male population. Worsening of the gender ratio is due to the high premature mortality of men. In addition, for the last 30 - 40 years, the population of working age has significantly reduced, and there was a significant population "aging", which negatively affects the demographic situation in the region (see Figure 4).

In the age-gender structure of the region population, the trend of the female population number exceeding the number of male population still exists. There are 1000 men for $1200-1250$ women. Worsening of the gender ratio is due to the high premature mortality of men (Kuznetsov, V., et al. (2014)). 


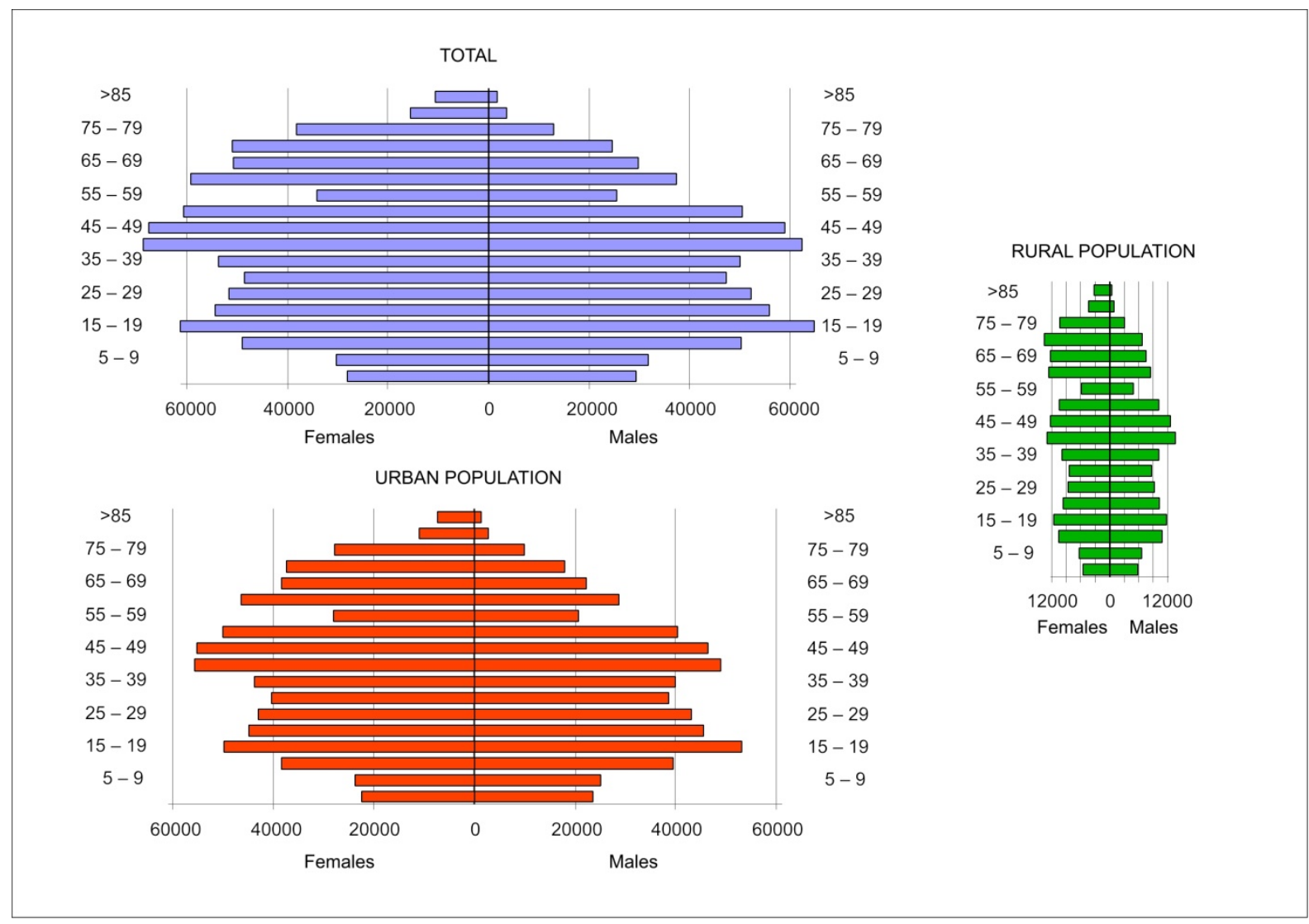

Figure 4. Age and gender structure of the population of the Vladimir region, characteristic of the Klyazma basin

The population of working age continues to decrease (16-59 year old men, 16-54 year old women). 1000 people of the working age correspond to 620 persons of the non-working age, including children and adolescents -230 persons, people of retirement age - 390 (2008).

The average life expectancy in Russia in 1896 - 1897 was 29.43 years for men, 31.69 for women. According to Rosstat, the life expectancy in Russia in 2012 amounted to 70.3 years ( 64.6 for men and 75.9 for women). In the Vladimirsky region, the corresponding figure was 68.6 years, in the Ivanovsky -69.3 , in the Moscow region 70.4. The prognosis for 2020: the average life expectancy in Russia will be 71.8 years, including women -77.3 years, men -66.2 years.

The national composition of the population majority - up to $95 \%$ - Russians. The Moscow region and major cities are home to a large number of migrant workers, mainly from the southern regions of the Russian Federation and CIS countries; in some cities they formed a places compact living, which contributes to ethnic tension. Most people in the region are Orthodox, in recent years a number of adherents of Islam and other faiths increases.

\section{Conclusion}

Thus, conducted, within the boundaries of the river basin, studies show that river basins can be considered as the basic biosphere structure within which it is advisable to analyze not only the state of natural and man-made ecosystems and land-use characteristics, but also the nature of population distribution and basic demographic indicators, which are closely linked with the involvement intensity of environmental and territorial geographical systems, which river basins actually are, in the economic turnover and nature management.

The territory of the Klyazma river basin has a long historical development. Currently it is in the area of complex and challenging demographics and experiences another restructuring of environmental systems and landscape environment. Measures taken by the Government of the Russian Federation to change the situation in the regions of Central Russia are not sufficient. The tradition of a large family in Russia is lost, but giving birth to a second 
and a third child is still an acceptable value, and possibly with creating of appropriate financial and living conditions. The state demographic policy in the country should be focused on the health status of the population, an increase in life expectancy and lower mortality; birth rate stabilization, promoting giving birth to a second and a third child; strengthening the family; attracting immigrants professing Russian ethno-cultural traditions from other regions, including neighbouring countries; preservation and reconstruction of the social, economic and infrastructure objects in the peripheral and interior regions.

It should be noted that this article does not give sufficient analysis of the correlation between demographic processes and economic factors, and a more detailed analysis of the causes and consequences of the growth of urban centres and their impact on the functioning of the river basin is also required. Researches in this direction are expected to be continued in the longer term.

\section{Acknowledgements}

The scientific publication is a part of the state task VISU № 37.2108.2014/K to perform state works in the field of scientific activity.

\section{References}

Benini, L., Bandini, V., Marazza, D., \& Contin, A. (2010). Assessment of land use changes through an indicator-based approach: A case study from the Lamone river basin in Northern Italy. Ecological indicators, 10, 4-14. http://dx.doi.org/10.1016/j.ecolind.2009.03.016

Blakemore, M. (1988). Cartografy and geografic information systems. Progr. Hum. Geogr., 4(12), 525-537.

Clas, F., \& Lämås, T. (2000). Studia forestalia suecica. Swed. univ. of agr. Sciences. Fac. of forestry, Uppsala, Sweden, 208. Different management regimes in a boreal forest landscape: ecological and economic effects Clas Fries. Landscape Boreal Forest Management in Sweden, Uppsala.

Demographic Yearbook of Russia. (Statistical Yearbook). (2000-2013). Moscow: Federal State Statistics Service (Rosstat).

Dengiz, O., \& Sağlam, M. (2012). Determination of land productivity index based on parametric approach using GIS technique. Eurasian Journal of Soil Science, 1, 51-57.

Dobrovolsky, G. (2005). Floodplains soils of the Russian Plain center. Moscow: MSU.

Golubeva, L. (1987). Merya. Finno-Ugrians and Balts in the Middle Ages. Archaeology of the USSR. Moscow.

Jia, X., Shao, M., Wei, X., Horton, R., \& Li, X. (2011). Estimating total net primary productivity of managed grasslands by a state-space modeling approach in a small catchment on the Loess Plateau, China. Geoderma, 160, 281-291. http://dx.doi.org/10.1016/j.geoderma.2010.09.016.

Kochurov, B. (1992). Environmental situations and their forecast. Geography and natural resources, 2, 5-13.

Kolomyts, E. (2005). Boreal ecotone and geographic segmentation: atlas-monograph. Moscow: Science.

Korytny, L. (1991). Basin approach in geography. Geography and natural resources, 1, 161-166.

Korytny, L. (2001). Basin concept in wildlife management. Irkutsk: Publishing House of the Institute of Geography of the Russian Academy of Sciences.

Krasnov, Y. (1993-1995). Archaeological Map of Russia. Parts: Vladimirskaya, Ivanovskaya, Moscovskaya and others regions. Moscow: Institute of Archaeology, Russian Academy of Sciences.

Kuznetsov, V., Gavrilov, O., Maltsev, I., \& Repkin, R., et at. (2014). Geography of the Vladimir region, Study guide. Moscow: Moscow State University. ISBN 978-5-19-010882-8.

Makarov, N., Fedorina, A., \& Shpolyansky, S. (2013). Land and the city: medieval villages in the Vladimir-on-Kliazma district. Russian archeology, 4, 58-74.

Makarov, N., Leontiev, A., \& Shpolyansky, S. (2005). Rural settlements in the central part of Suzdal in the end of the $1^{\text {st }}$ - the first half of the $2^{\text {nd }}$ millennium AD: new materials. Rus in the IX-XIV centuries. Interaction between the North and the South. Moscow.

Mishchenko, N. V., Trifonova, T. A., \& Shoba, S. A. (2009). Soil Productive Potential in Small River Basins, ISSN 0147-6874. Moscow University Soil Science Bulletin, 64(4), 168-174. (C) Allerton Press, Inc., 2009. Original Russian Text (C) Vestnik Moskovskogo Universiteta. Pochvovedenie, 2009, No. 4, pp. 26-32. http://dx.doi.org/10.3103/s014768740904005X

Muravyova, M. (2011). Rural Demography of Russia as a factor of sustainable socio-economic development. 
Herald of the Saratov State Agricultural University named after Vavilov N.I., 11, 71-75.

Population census 2010. (2010). Population of Russia, its federal districts, subjects of the Russian Federation, city districts, municipal districts, urban and rural settlements. Federal State Statistics Service (Rosstat).

Population of the Russian Federation in respect of municipalities for the 1st of January 2013. (2013). Moscow: Federal State Statistics Service (Rosstat). (Table 33. Population of urban districts, municipal districts, urban and rural settlements, urban populated areas, rural populated areas).

Repkin, R., \& Tyulina, V. (2002). Research of small rivers catchments basins. Geographical Regional Studies: Proceedings of the $4^{\text {th }}$ All-Russian research-to-practice conference. Vladimir: VSPU.

Tian, H., Chen, G., Liu, M., Zhang, C., Sun, G., Lu, C., Xu, X., Ren, W., Pan, S., \& Chappelka, A. (2010). Model estimates of net primary productivity, evapotranspiration, and water use efficiency in the terrestrial ecosystems of the southern United States during 1895-2007. Forest ecology and management, 259, 1311-1327. http://dx.doi.org/10.1016/j.foreco.2009.10.009

Trifonova T. A., Shirkin, L. A., Mishchenko N. V. (2012). Simulation of stationary states of a phitocenosis - soil system based on the example of the Klyaz'ma river basin. Eurasian soil science, 45(8), 793-801. http://dx.doi.org/10.1134/s1064229312080078

Vodarsky, Y., \& Kabuzan, V. (2011). Territory and population of Russia in XV - XVIII centuries. The Russian empire. From the origins to the beginning of the XIX century. Essays on the socio-political and economic history. Editors Aksenov, A., Vodarsky, Y., Nikitin, N., \& Rogozhin, N. Moscow: Russkaya panorama. ISBN 978-5-93165-267-2.

\section{Copyrights}

Copyright for this article is retained by the author(s), with first publication rights granted to the journal.

This is an open-access article distributed under the terms and conditions of the Creative Commons Attribution license (http://creativecommons.org/licenses/by/3.0/). 